\title{
Integrated marine measurements in Civitavecchia, near Rome
}

\author{
G. Zappalà ${ }^{1,2}$, G. Caruso $^{1}$, V. Piermattei ${ }^{2}$, S. Bonamano ${ }^{2}$, \\ A. Madonia ${ }^{2}$, A. D. Cicco ${ }^{2}$, R. Martellucci ${ }^{2}$ \& M. Marcelli ${ }^{2}$ \\ ${ }^{1}$ Istituto per l'Ambiente Marino Costiero (IAMC), \\ National Research Council, Messina, Italy \\ ${ }^{2}$ DEB Experimental Oceanology and Marine Ecology Laboratory, \\ Tuscia University, Viterbo, Italy
}

\begin{abstract}
Integrated observing systems are important tools for marine monitoring, as they allow acquisition and record of ecological time series. Integration of time-series monitoring efforts is recognised as a priority in national and international scientific programs, being necessary to better understand how marine ecosystems will change not only in response to anthropogenic impacts, but also to identify trends in their natural evolution. Coastal ecosystems are areas particularly sensitive to climate changes and human impacts, consequently they deserve to be the subject of time-series observation programs. The Laboratory of Experimental Oceanology and Marine Ecology of Tuscia University is located in Civitavecchia's harbour; representing one of the main laboratories for marine experimental research on the Tyrrhenian Sea, it focuses its activities both on open sea and coastal processes. Although its recent constitution, it has already gained a good experience participating in national and European research projects, in many oceanographic cruises and collaborating with public Institutions. Integrated marine observation activities were performed in the coastal area of Civitavecchia, an Italian city near Rome. Heart of the system was a platform moored near the harbour measuring every 20 minutes the main water parameters (Temperature, Conductivity, Dissolved Oxygen, Turbidity, Fluorescence). A GPS gave the buoy position that was verified to be in the allowed range; in negative case an alarm was immediately sent via SMS to the mobile phones of the buoy crew. Another system verified the functionality of the buoy simply generating calls to the buoy modem; a "no response" generated an
\end{abstract}


alarm to the crew. The acquired data were transmitted twice a day to the "base" station (the Laboratory) via e-mail and FTP using a cellular modem. Another fixed station in the harbour measured Temperature, Conductivity, Dissolved Oxygen, pH. Numerical models played a fundamental role allowing us to estimate the dispersion dynamic of different kinds of particles (pollutants, suspended matter, bacteria, etc.). The accumulation and the dynamics of spreading and transport of potentially infectious microorganisms were simulated, using physical and microbiological in situ collected data to feed and validate the model results. Satellite observations gave an estimate of Chlorophyll- $a$ and suspended matter. The system demonstrated an efficient, flexible and costeffective way to assess environmental conditions. Some recent results are reported.

Keywords: environment monitoring, observatory network, remote sensing, fecal pollution, mathematical models.

\section{Introduction}

The awareness of the limited availability of water resources and of the potential natural or anthropogenic threats they are exposed to, in relation to global climate changes, has resulted in increased interest towards marine systems monitoring throughout the world. Particularly, in European Countries, current legislation concerning water bodies (Water Framework Directive, 2000/60/EC Directive and further improvements, Marine Strategy Framework Directive 2008/56/EC) focuses on the achievement of their Good Environmental Status (GES) in terms of biological diversity and overall ecological quality status; special attention is paid to GES definition according to appropriate descriptors, among which both physical and chemical characteristics of aquatic systems and the composition of the biota, possible disturbance by introduction of microbial pathogens, chemical contaminants, or non indigenous species, and to the application of appropriate measures for its maintenance. Within this context, increased importance has been addressed to the safeguard of coastal ecosystems, which are areas particularly sensitive to climate changes and human impacts, consequently they need to undergo time-series observation programs. Particularly, Long-Term Observational Systems (L-TER) have been recognised to represent a winning strategy to comply with the objectives of environmental protection and sustainability, since they provide a complete picture of the health status of a specific environment and allow us to assess whether its conditions evolve towards improvement, worsening, or are stable. Integration of time-series monitoring efforts is recognised as a priority in national and international scientific programs, being necessary to better understand how marine ecosystems will change not only in response to anthropogenic impacts, but also to identify trends in their natural evolution.

Recent advances in technological equipments and instruments for environmental assessment have provided the needed support to this new concept of environmental quality and protection. Many systems, like buoys, remote sensing by satellites, punctual measurements by dedicated vessels, voluntary 
observing ships, can be combined, each one characterised by specific advantages for marine environment monitoring and early warning of potential risks. Integration of "in situ" collected data with the use of mathematical models is also considered a needed step to depict the dynamics of spreading and transport of potential contaminants at sea.

\section{Materials and methods}

\subsection{The study area}

The coastal area of Civitavecchia and Santa Marinella (Fig. 1), located along the Tyrrhenian Sea, in the Rome province, is the perfect example of a coastal ecosystem affected by multiple human activities: in spite of its high ecological value and relevance for recreational use, it hosts one of the biggest European harbours, as well as production parks including power and aquaculture plants. The beach of Santa Marinella is a part of a bay about $1 \mathrm{~km}$ wide, comprised between the promontory of Cape Linaro, in the North, and Cape Anzio, in the South. It is characterized by a jagged and rocky coastline, gradually and partly replaced by a purely sandy coast, with the presence also of low calcarenites cliffs going towards the mouth of the Tiber river (about $55 \mathrm{Km}$ south). Surrounding hills partly protect the area from southwards and W-SW-wards winds, so limiting their influence on water masses. The town of Santa Marinella is a major touristic destination, with a resident population of about 18000 people, almost doubled in summer thanks to the charm of numerous hotels and bathing facilities.

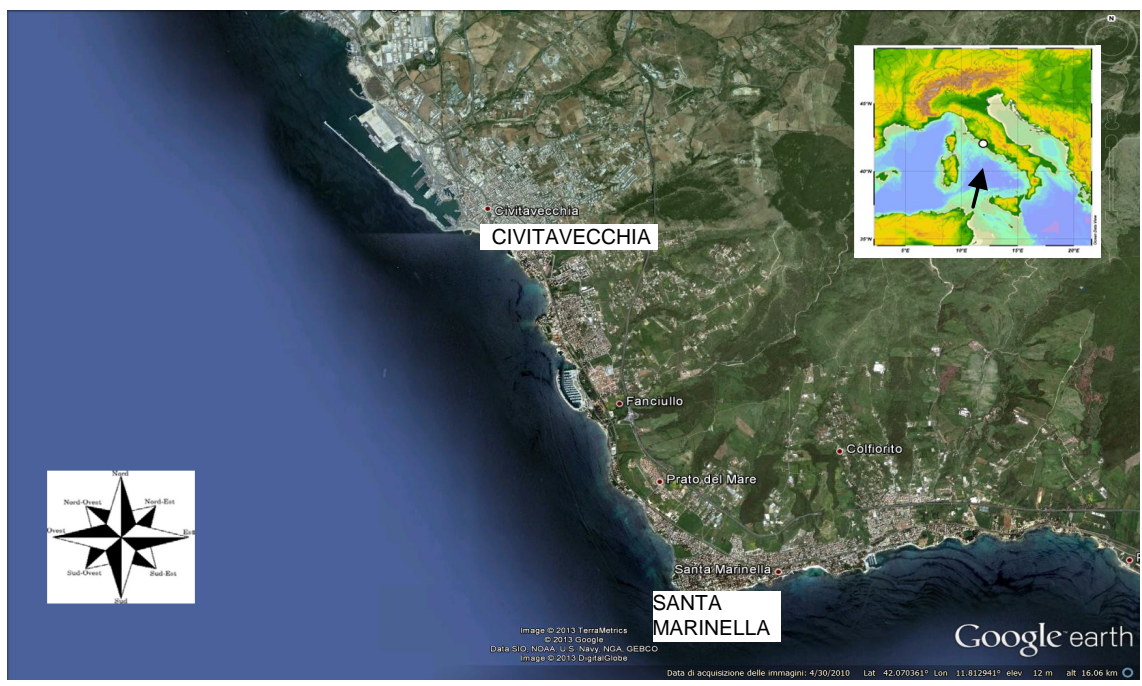

Figure 1: $\quad$ The study area (base image from Google Earth). 
In the last fifty years, four submerged and four emerged barriers were built in front of Santa Marinella beach to reduce the incoming wave energy, so limiting erosion phenomena. Such barriers have created a semi-enclosed basin separating the coastal waters (maximum depth about $3 \mathrm{~m}$ ) from the open sea, causing, together with wind directions, especially in summer, lower potential contaminants diffusion, due to the reduced water masses renewal. In addition, inputs from rivers and wastewaters treatment plants may increase the risk of contamination by pathogens.

\subsection{Automatic measurements}

A platform, Fig. 2, was moored near Civitavecchia harbour; it has a rectangular shape, about $2 \mathrm{~m} \times 4 \mathrm{~m}$ size and was first used in Sicilian waters at the beginning of the century [1-5]. The data acquisition and transmission control software derives from the modular program that was first used for the "advanced technology coastal monitoring platform” in Messina, and then modified for an offshore platform near Venice, and for an automatic multiple launcher for expendable probes [6-14]. The hardware uses a PC-like architecture; the software is written in Microsoft compiled Basic and in Assembly language; both are better described in $[15,16]$.

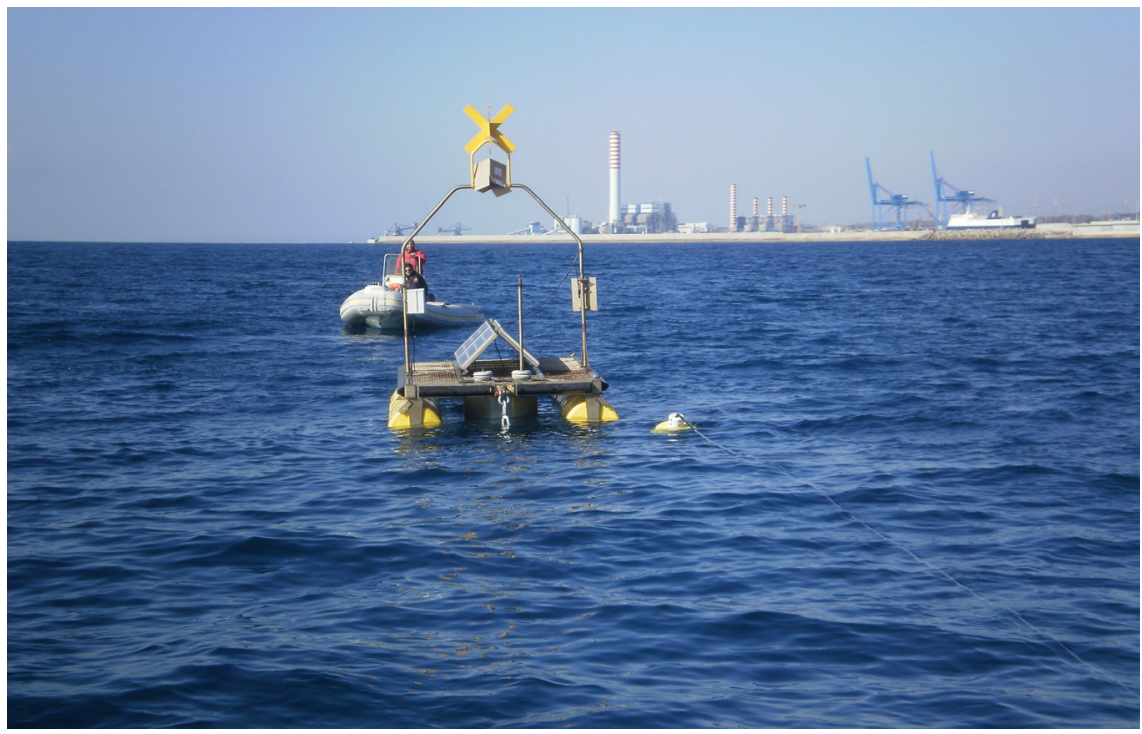

Figure 2: $\quad$ The platform moored near Civitavecchia harbour.

The new version of the hardware-software system implements a double alarm system; the first (buoy based) controls the buoy position given by a GPS; should the buoy exceed the allowed range (so meaning that the mooring is broken), an SMS alarm message is immediately sent to the mobile phones of the buoy crew. 
The second alarm (land based) simply verifies the buoy functionality calling the buoy modem. In case of no response an alarm message is sent to the buoy crew.

Moored near Civitavecchia harbour, the systems perform a full set of measurements of the main water parameters (Temperature, Conductivity, Dissolved Oxygen, Turbidity, Fluorescence). The acquired data are transmitted twice a day to the "base" station (the Laboratory) via e-mail and FTP using a cellular modem.

Another fixed station in the harbour measures Temperature, Conductivity, Dissolved Oxygen, $\mathrm{pH}$ and transmits data twice a day to the FTP site.

Both the stations have an acquisition interval of twenty minutes.

\subsection{Manual measurements}

\subsubsection{Water sampling}

Water surface samples for the "in-situ" determination of Chlorophyll- $a$ and Total Suspended Matter (TSM) at the "platform-station” (Fig. 3) are collected weekly. Seawater for pigment analysis is also pre-filtered by a net of $250 \mu \mathrm{m}$ to remove zooplancton and macroalgae. Both samples (Chlorophyll- $a$ and TSM) are stored in dark bottles.

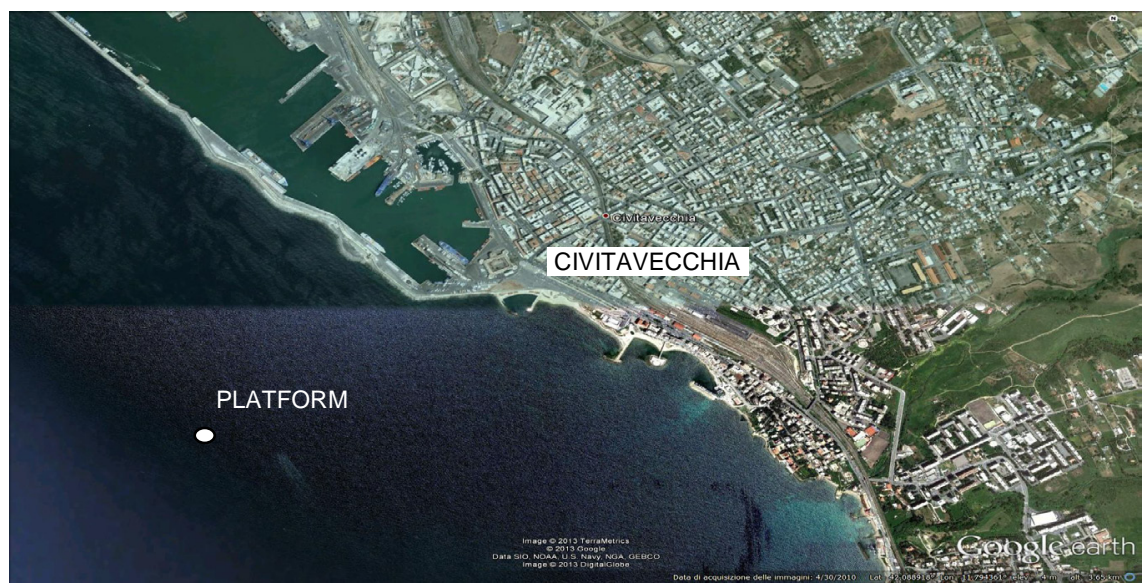

Figure 3: $\quad$ The platform position (base image from Google Earth).

\subsubsection{Pigment analysis}

At the Laboratory of Experimental Oceanology and Marine Ecology of the Tuscia University, known volumes of pigment water samples are collected on $\mathrm{GF} / \mathrm{F}$ glass-fibre filters and extracted at $4^{\circ} \mathrm{C}$, for at least $24 \mathrm{~h}$ in $90 \%$ acetone.

The measurements are performed following a spectrophotometric method [17]. Chlorophyll- $a$ concentrations are determined by the protocol developed by Lorenzen [18]. The analyses are carried out using a Shimadzu spectrophotometer “UV mini 1240” model (5 cm cuvette pathlength). 


\subsubsection{Solid suspended matter analysis}

At the laboratory known volumes of TSM water samples are collected on predried and pre-weighed GF/C glass-fibre filters.

Sample analyses are carried out following the gravimetric method [19].

\subsubsection{Detection and quantification of Escherichia coli through fluorescent antibody technique}

Water samplings for fecal pollution monitoring were performed to cover the whole bathing season, starting from the month of July until September 2012. Seawater was collected from the surface depth of four stations differently located along the shoreline of Santa Marinella (SM) (1, 2, 2A, 2B) (Fig. 4). A total of 4 samplings were carried out: on July 4, August 8 and 20, September 12.

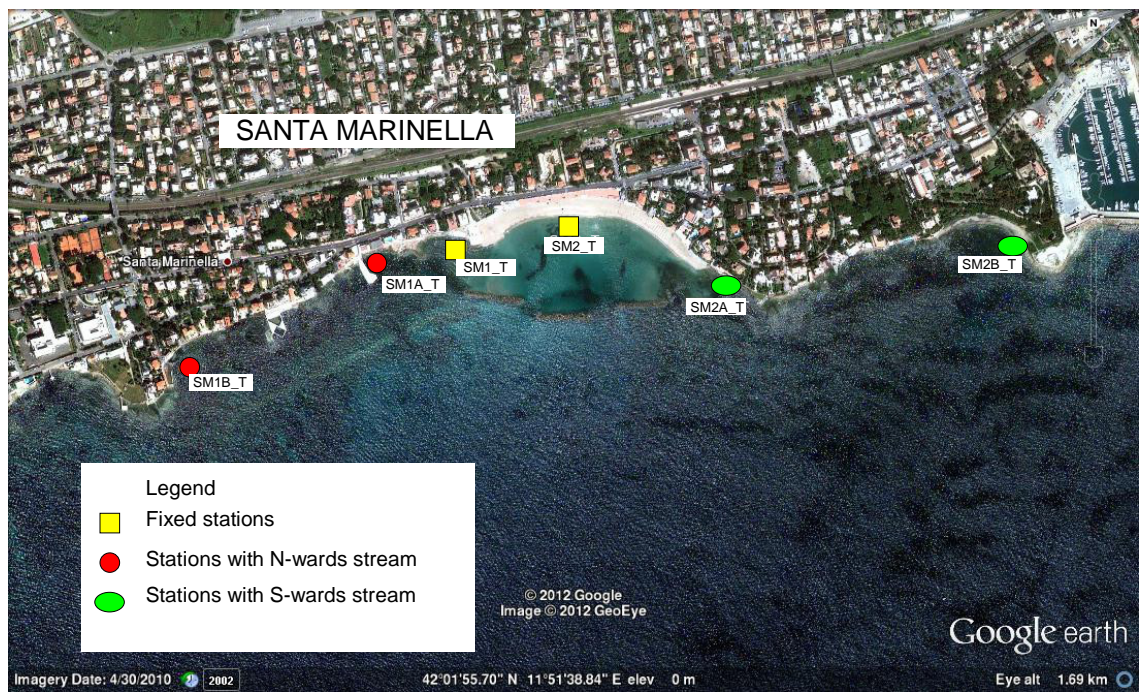

Figure 4: Location of the sampling sites (base image from Google Earth).

Volumes of $100 \mathrm{ml}$ of water were analysed by fluorescent antibody method (FA) under epifluorescence microscope, simultaneously to the direct count through culture of $0.45 \mu \mathrm{m}$ filtering membranes on ECD-MUG agar plates (Biolife) at $35^{\circ} \mathrm{C}$ for 24 hours. The indirect fluorescent antibody procedure based on polyclonal immune sera (Murex Escherichia coli agglutinating sera, mix of polyclonal $2+3+4$, diluted in a 1:80 ratio with phosphate buffered saline as the working solution) was used to stain specifically E. coli cells [20]. Microscopical and culture counts were expressed as cells and colony forming units (CFU) per $100 \mathrm{ml}$ of water, respectively.

\subsubsection{Satellite observations}

The area of interest is also monitored by satellite observation technologies. Maps of Chlorophyll $a$ and TSM, when their data are available, are generated daily. 
Satellite data for this work were from MODIS (Moderate Resolution Imaging Spectroradiometer) sensor, a basic instrument aboard the Aqua (EOS PM) spacecraft. Aqua's orbit around the Earth is sun-synchronous, near-polar, and circular. Aqua passes from the South to the North over the Equator in the afternoon (1.30 p.m. UTC) and viewing the entire Earth's surface every 12 days, so acquiring, every day in every place, MODIS data in 36 spectral bands ranging, in wavelengths, from $0.4 \mu \mathrm{m}$ to $14.4 \mu \mathrm{m}$ [21]. These different bands produce three different type of images with a $250 \mathrm{~m}, 500 \mathrm{~m}$, and $1 \mathrm{~km}$ spatial resolution, respectively.

The spectral bands between 405 and $877 \mathrm{~nm}$ are the "ocean color MODIS bands" and give information about the biogeochemical status of the ocean. These bands have a $1 \mathrm{~km}$ spatial resolution.

The Ocean Color MODIS data for this work were downloaded directly by the NASA website [22] at level L1-A (Level L1-A data products in MODIS contain the raw radiance counts, spacecraft and instrument telemetry and calibration data).

Data processing was carried out by the SeaDAS utility, an image analysis package for the processing, display, analysis, and quality control of ocean color data, supplied by the same NASA [23]; it was set out in 4 steps:

- $\quad$ at the first, a separated Geo-file that contains the navigation data for the geolocation must be generated.

- then a L1-B data product, that contains the calibrated at-aperture (topof-atmosphere) radiances derived from L1A product, was generated.

- $\quad$ at the third step the L2 product, that contains geophysical values data for each pixel, derived from the Level-1B radiances by applying atmospheric corrections and bio-optical algorithms, was generated. L2 product data are geolocated data.

- $\quad$ at the end, every geophysical parameter contained in the L2 product was remapped with cylindrical projection and then a data file and a map to display the data were created for each parameter.

\subsubsection{Use of mathematical models}

Wind and wave data were used to calculate coastal marine currents by twodimensional (ADvanced CIRCulation, ADCIRC, and STeady-state spectral WAVE, STWAVE) and three dimensional models (DELFT3D-FLOW and Simulating Waves Nearshore, SWAN) with a high spatial-time resolution.

Two-dimensional hydrodynamic field was obtained by the steering module that couples the ADCIRC [24] and the STWAVE [25] models.

ADCIRC is a time-dependent, finite-element numerical model that computes water-surface elevations and velocities at grid nodes with a resolution of about 20 meters. ADCIRC can be forced by several processes simultaneously, including gradients in wave radiation stress. STWAVE is a steady-state finitedifference model that calculates wave spectra at each cell in a rectangular grid. STWAVE is driven by offshore wave spectra and local winds and has provision to accept optional current vector fields. 
In the coastal area, sea currents distribution was also described by the coupling of the Delft3D-FLOW and SWAN models. The Delft3D-FLOW model simulates three-dimensional (depth-averaged) unsteady flows resulting from meteorological phenomena, solving non-linear shallow water equations that are formulated in orthogonal curvilinear coordinates or in the spherical coordinates. These equations are derived from the three-dimensional Navier-Stokes equations for incompressible free surface flow. In the vertical direction the Delft3D-FLOW model applies a so-called $\sigma$ co-ordinates system. The SWAN model is a thirdgeneration wave model that computes random, short-crested wind-generated waves in coastal regions and inland waters.

The hydrodynamic forcing was used to simulate the dispersion of potentially infectious microorganisms in the study area in order to assess potential sanitary risks related to the use of seawaters contaminated by bacterial pathogens [26].

Depending on the culture or microscopical method of microbiological analysis used to determine $E$. coli concentration in seawaters, two different dispersion models were used: PTM model [27] that simulates conservative substances and Delft3D-WAQ model that takes into account the transport and dispersion of substances subjected to decay.

To simulate the distribution of potentially infectious microorganisms in the near-shore coastal waters by PTM model, it was assumed that all coliform bacteria, regardless of their physiological state, can attach to organic or inorganic particulate [28]. PTM is an ERDC-developed model designed specifically to track the fate of point-source constituents (sediment, chemicals, debris, etc.) released from local sources such as dredges, placement sites, outfalls, etc. in complex hydrodynamic and wave environments. In addition to coliform bacteria concentration, the simulations were performed using the hydrodynamic field obtained from two-dimensional models and some data (temperature, conductivity and turbidity) acquired from the moored platform.

More recently in the same area of study the dispersion of coliform bacteria was simulated by the Delft3d-WAQ model that takes into account their decay rate and the three-dimensional hydrodynamic field (obtained by coupling of the Delft3d-FLOW and SWAN models). The mortality rate of $E$. coli depends on the ambient salinity (or chloride concentration), temperature and the intensity of the UV radiation. Delft3D-WAQ solves the equations for transport and physical, (bio)chemical and biological processes.

\section{Results and discussion}

The coastal area of Civitavecchia and S. Marinella represents the perfect test bench for an integrated environmental monitoring due to its multiple anthropic uses and impacts, hosting one of the biggest European harbours, big production parks including a power plant, mariculture, fishing and tourism. Some sample automatic measurements related to a late winter and to a summer period are shown in Fig. 5. 

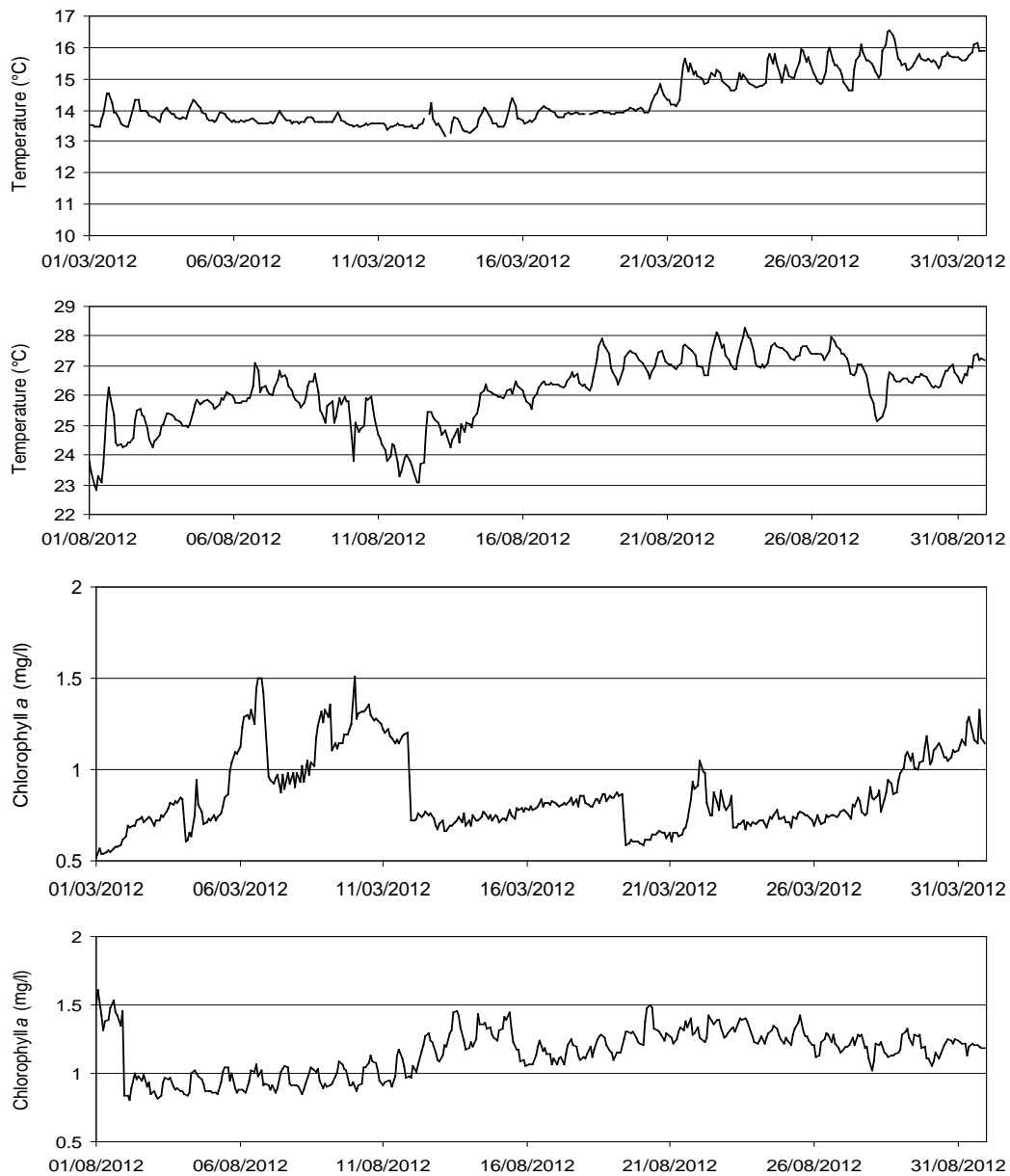

Figure 5: $\quad$ Temperature and Chlorophyll $a$ measured by the platform.

Temperature profiles recorded in late winter 2012 appear quite homogeneous, with values oscillating around $14^{\circ} \mathrm{C}$ and with evident daily excursions; from Day March, 16, an increasing trend towards the spring season is found. Conversely, high variability is observed in the $\mathrm{T}$ profiles measured during the summer season, with values reaching $28^{\circ} \mathrm{C}$ during the second half of the August month.

In winter, Chlorophyll-a concentration describes a variable distribution, with values exceeding $1 \mu \mathrm{g} / \mathrm{l}$ on March 6 and from Day 28 onwards, in relation with the increasing $\mathrm{T}$ trends. A more pronounced variability is evident in Chlorophyll$a$ values during summer, which undergo daily variations and increase up to $1.5 \mu \mathrm{g} / \mathrm{l}$ in the second half of August.

The values of E. coli obtained at the examined sites are shown in the Fig. 6 . The highest E. coli abundances are found at the station SM1 during the August 
samplings, while the lowest in July. The stations SM2A and SM2B are characterized by clean waters, while at station SM1 the concentration of E. coli always exceeds the threshold level reported by the recent Bathing water Directive 2006/7/EC (250 CFU/100ml for excellent water quality, 500 $\mathrm{CFU} / 100 \mathrm{ml}$ for good water quality).

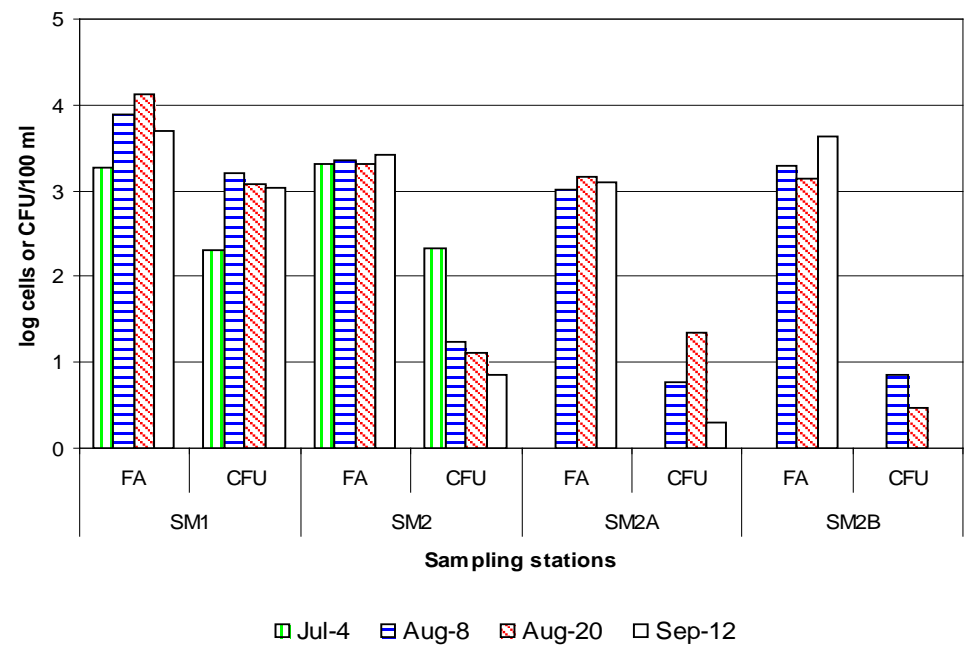

Figure 6: Escherichia coli abundances recorded by Fluorescent antibody (FA) and culture (CFU) methods at the sampling sites.

Apart from station SM1, the degree of faecal pollution estimated during the present study is similar to that previously observed in the same area [26], when faecal coliforms concentrations in the Santa Marinella area ranged from 0 to 150 CFU/100 ml. Lower values were detected in the first half of August 2011 compared to the second one (mean values: 8.6 and $56 \mathrm{CFU} / 100 \mathrm{ml}$, respectively), with a maximum value of $150 \mathrm{CFU} / 100 \mathrm{ml}$ recorded on Day 22 . Variability in bacterial concentration was explained by exposure to high solar radiation values and intense meteo-marine conditions, during the first half of the month, which are known to decrease the survival of enteric bacteria in marine environments [29]. It should be noted, however, that the Fluorescent antibody method used in the present investigation allowed a rapid screening of the fecal contamination of the examined area, through the quantification of total E. coli cells unless of their physiological state (living, actively respiring or dead cells). To give more insights on this feature, the same protocol should be combined with viability staining like cyanotetrazolium chloride (CTC) or propidium iodide (PI), as reported in previous studies for E. coli [20, 30] as well as for total bacterioplankton [31].

The TSM image (Fig 7 left) shows an increasing gradient moving from offshore to the coast, dominated by the terrestrial influence. For this reason the highest concentrations of suspended solid matter can be found near the mouths 
of rivers, particularly of Marta and Mignone rivers; maximum values (about 10 $\mathrm{mg} / \mathrm{l}$ ) are reached at the mouth of the Tiber river, where the dynamics of transportation of the solid matter, even many kilometers far away from the coast, are also evident.

The trend of Chlorophyll-a, (Fig. 7 right), as observed for that of TSM, increases towards the coast, with a range from 0 to about $3 \mu \mathrm{g} / \mathrm{l}$. Higher concentrations of Chlorophyll $a$, with peaks that reach up to $5 \mu \mathrm{g} / \mathrm{l}$, are detected near the mouths of major rivers, thanks to the inputs of nutrients from their waters.
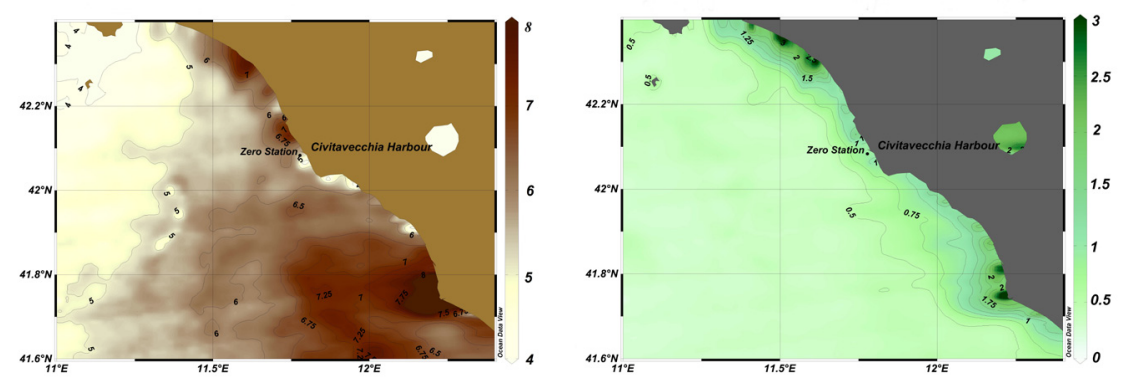

Figure 7: January $7^{\text {th }} 2013-$ TSM and Chlorophyll- $a$ patterns by satellite.

The proposed methodology of integrated observing systems includes numerical models that play a fundamental role to simulate conservative (e.g. sediment) and decayable (e.g. coliform bacteria) substances transport processes in the near-shore coastal waters. The use of mathematical models provides integrated responses about the level of contamination and pollution in marine ecosystems, enabling local authorities to set up suitable measures to protect and conserve areas and species which are most threatened.

In the last years the modelling approach was used to determine the accumulation and the dynamics of spreading and transport of potentially infectious microorganisms in Civitavecchia bathing areas. In addition to the water quality indicator measurements, current speed and direction, temperature and salinity were also measured. Moreover solar radiation and wind speed and direction were available from weather station of Port Authority of Civitavecchia while wave parameters were collected from wave-buoy of RON (Rete Ondametrica Nazionale). This dataset was used to set-up, validate and calibrate numerical models that describe coastal marine currents and the fate of coliform bacteria load discharged from sewage outfalls.

Using two-dimensional mathematical model (PTM) the dispersion of coliform bacteria was simulated, considered only dependent on physical transport processes [32]. In the simulated scenario of the $4^{\text {th }}$ August 2011 (Fig. 8) the bacterial load in the S. Marinella beach bathing area shelves after $28 \mathrm{~h}$. 

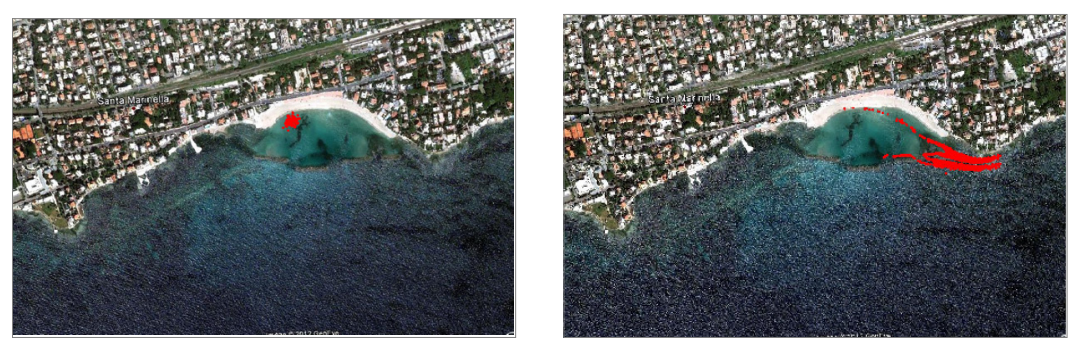

Figure 8: August $4^{\text {th }}$ 2011. Faecal coliform dispersion simulated of 4th August 2011 with PTM model: initial condition (left) and 28 hours later (right).

The simulations produced with three-dimensional model (Delft3d-waq), obtained using the concentration of coliform bacteria estimated by the culture method as initial condition, have allowed to evaluate the distribution of the coliform bacteria in seawater taking into account their decay rate. The scenario of $8^{\text {th }}$ August 2012 (Fig. 9) shows the decrease of initial bacteria load from maximum value of $125 \mathrm{MPN} / 100 \mathrm{ml}$ to $15 \mathrm{MPN} / 100 \mathrm{ml}$ during within 24 hours moving from the sewage outfall to the centre of bathing area.


Figure 9: August $8^{\text {th }}$ 2012. Escherichia coli dispersion simulated with the Delft3d-WAQ model: initial condition (left) and 24 hours later (right).

\section{Conclusions}

The integrated use of the described systems, together with other innovative ones, like the SAVE (Sliding Advanced VEhicle) - a device able to be towed from a small (8-10 meters) boat, performing measurements and water samplings on the water column [33, 34] - gives a powerful, efficient flexible and cost-effective instrument to assess environmental status and validate satellite observation and mathematical models [35]. The mathematical models applied to the monitoring of microbiological quality of seawater are a suitable tool for early warning of fecal pollution, allowing the prevention of possible health risks. 


\section{References}

[1] Zappalà, G., Caruso, G., and Crisafi, E., The "SAM" integrated system for coastal monitoring, Proc. of the $4^{\text {th }}$ International Conference on Environmental problems in Coastal Regions, ed. C.A. Brebbia, WIT Press: Southampton, 8, pp. 341-350, 2002.

[2] Zappalà, G., Caruso, G., and Crisafi, E., Coastal pollution monitoring by an automatic multisampler coupled with a fluorescent antibody assay. Proc. of the $5^{\text {th }}$ International Conference on Environmental problems in Coastal Regions, eds. C.A. Brebbia, J.M. Saval Perez, L. Garcia Andion \& Y. Villacampa Esteve, WIT Press: Southampton, 10, pp. 125-133, 2004.

[3] Zappalà, G., Azzaro, F., A new generation of coastal monitoring platforms, Chemistry and Ecology, 20, pp. 387-398, 2004.

[4] Zappalà, G., Caruso, G., Azzaro, F., and Crisafi, E., Marine environment monitoring in coastal Sicilian waters. WIT Transactions on Ecology and the Environment, ed. C.A. Brebbia, WIT Press: Southampton, 95, pp. 337-346, 2006.

[5] Marcelli, M., Piermattei, V., Zappalà, G., Advances in low cost marine technologies. WIT Transactions on Modelling and Simulation, eds. G.M. Carlomagno \& C.A. Brebbia, WIT Press: Southampton, 51, pp. 497-507, 2011.

[6] Zappalà, G., Crisafi, E., Caruso, G., Azzaro, F., Magazzù, G., Coastal monitoring by an advanced technology platform. Proc. Oceanology International 98 - The Global Ocean, Brighton (UK) 10-13 march 1998, I, pp. 69-84, 1998.

[7] Zappalà, G., Alberotanza, L., Crisafi, E., Automatic monitoring on an unmanned offshore platform. Proc. The Marine Technology Society Annual Conference - Ocean Community Conference '98 - Celebrating 1998 International Year of the Ocean, Baltimore (USA) 16-19 November 1998, I, pp. 585-589, 1998.

[8] Zappalà, G., Alberotanza, L., Crisafi, E., Assessment of environmental conditions using automatic monitoring systems. Proc. MTS-IEEE Oceans '99 - Riding the Crest into the 21st Century, Seattle (USA) 13-16 September 1999, II, pp. 796-800, 1999.

[9] Zappalà, G., Caruso, G., and Crisafi, E., Design and use of advanced technology devices for sea water monitoring. Operational Oceanography. Implementation at the European and Regional Scales, eds. N.C. Flemming, S. Vallerga, N. Pinardi, H.W.A. Behrens, G. Manzella, D. Prandle, J.H. Stel, Elsevier Oceanography Series, 66, pp. 273-280, 2002.

[10] Zappalà, G., Advanced technologies: equipments for environmental monitoring in coastal areas. Science-technology synergy for research in marine environment: Challenges for the XXI Century, eds. L. Beranzoli, P. Favali, G. Smriglio, Elsevier Developments in Marine Technology, 12, pp. 261-268, 2002.

[11] Zappalà, G., Caruso, G., Azzaro, F., and Crisafi, E., Integrated environment monitoring from coastal platforms. Proc. $6^{\text {th }}$ International Conference on 
the Mediterranean Coastal Environment, MEDCOAST 03, ed. E. Ozhan, MEDCOAST, Middle East Technical University: Ankara, 3, pp. 20072018, 2003.

[12] Zappalà, G., Manzella, G., An automatic multiple launcher for expendable probes. Proc. Fourth International Conference on EuroGOOS. Operational Oceanography: Present and Future, eds. H. Dahlin, N.C. Flemming, P. Marchand \& S. E. Petersson, European Commission Publication Office, pp. 188-191, 2006.

[13] Zappalà, G., Reseghetti, F., and Manzella, G.M.R., Development of an automatic multiple launcher for expendable probes, Ocean Sciences, 3, pp. 173-178, 2007.

[14] Zappalà, G., Development of advanced instrumentation for operational oceanography. WIT Transactions on Modelling and Simulation, eds. C. A. Brebbia \& G. M. Carlomagno, WIT Press: Southampton, 46, pp 841-850, 2007.

[15] Zappalà, G., A software set for environment monitoring networks. Proc. of the Int. Conf. On Development and Application of Computer Techniques to Environmental Studies X. Envirosoft 2004, eds. G. Latini, G. Passerini, \& C. A. Brebbia, WIT Press: Southampton, pp. 3-12, 2004.

[16] Zappalà, G., A versatile software-hardware system for environmental data acquisition and transmission. WIT Transactions on Modelling and Simulation, eds. C. A. Brebbia \& G. M. Carlomagno, WIT Press: Southampton, 48, pp. 283-294, 2009.

[17] Lazzara, L., Bianchi, F., Falcucci, M., Hull, V., Modigh, M., Ribera d' Alcalà, M., Pigmenti clorofilliani. Nova Thalassia, 11, pp. 207-223, 1990.

[18] Lorenzen, C.J., Determination of chlorophyll and pheo-pigments: spectrophotometric equations. Limnology and Oceanography, 12, pp. 343346, 1967.

[19] APAT-CNR-IRSA, Manuali e Linee Guida, Metodi Analitici per le Acque 29/2003, III; sezione 6000 Metodi microbiologici- parte generale; sezione 7000 Metodi per la determinazione dei microrganismi indicatori di inquinamento e di patogeni, 2003.

[20] Caruso, G., Zappalà, G., Crisafi, E., Assessment of Escherichia coli viability in coastal Sicilian waters by fluorescent antibody and $\beta$ glucuronidase activity methods. WIT Transactions on Ecology and the Environment, ed. C.A. Brebbia, WIT Press: Southampton, 88, pp. 57-66, 2006.

[21] MODIS, http://modis.gsfc.nasa.gov/about/specifications.php

[22] OCEANCOLOR, http://oceancolor.gsfc.nasa.gov/

[23] SEADAS, http://seadas.gsfc.nasa.gov/

[24] Luettich, R.A., Westerink, J.J., and Scheffner, N.W., ADCIRC: An advanced three-dimensional circulation model for shelves, coasts, and estuaries, Report 1: Theory and methodology of ADCIRC-2DDI and ADCIRC-3DL. Technical Report DRP-92-6, U.S. Army Engineer Research and Development Center: Vicksburg, MS, pp. 1-137, 1992. 
[25] Smith, J.M., Sherlock, A.R., and Resio, D.T., STWAVE: Steady-State Spectral Wave Model user's guide for STWAVE Version 3.0, ERDC/CHL SR-01-01, U.S. Army Engineer Research and Development Center: Vicksburg, MS, 2001.

[26] Zappalà, G., Bonamano, S., Madonia, A., Caruso, G., Marcelli, M., Microbiological risk assessment in a coastal marine environment through the use of mathematical models. Water Pollution, 12, pp. 3-14, 2012.

[27] MacDonald, N. J., Davies, M.H., Zundel, A.K., Howlett, J.D., Lackey, T.C., Demirbilek, Z., and Gailani, J.Z., PTM: Particle tracking Model; Report 1: Model theory, implementation, and example applications. ERDC/CHL TR-06-20, U.S. Army Engineer Research and Development Center: Vicksburg, MS, 2006.

[28] Carlucci, A. F., and Pramer, D., Factors affecting the survival of bacteria in seawater. Applied Microbiology, 7 (6), pp. 388-392, 1959.

[29] Rozen, Y., Belkin, S., Survival of enteric bacteria in seawater. FEMS Microbiological Reviews, 25, pp. 513-529, 2001.

[30] Caruso, G., Mancuso, M., and Crisafi, E., Combined fluorescent antibody assay and viability staining for the assessment of the physiological states of Escherichia coli in seawaters. Journal of Applied Microbiology, 95, pp. 225-233, 2003.

[31] Caruso, G., Zappalà, G., Maimone, G., Azzaro, F., Raffa, F., Caruso, R., Assessment of the abundance of actively respiring cells and dead cells within the total bacterioplankton of the Strait of Messina waters. WIT Transactions on the built environment, ed. C. A. Brebbia, WIT Press: Southampton, 99, pp. 15-24, 2008.

[32] Fiandrino, A., Martin, Y., Got, P., Bonnefont, J.L., and Troussellier, M., Bacterial contamination of Mediterranean coastal seawater as affected by riverine inputs: simulation approach applied to a shellfish breeding area (Thau lagoon). Water Research, 37, pp. 1711-1722, 2003.

[33] Marcelli, M., Di Maio, A., Piermattei, V., Zappalà, G., and Manzella, G., Development of new technologies for the high variability phenomena data acquisition in the MFSTEP-VOS project. Proc. Fourth International Conference on EuroGOOS. Operational Oceanography: Present and Future, eds. H. Dahlin, N.C. Flemming, P. Marchand \& S. E. Petersson, European Commission Publication Office, pp. 184-187, 2006.

[34] Zappalà, G., Marcelli, M., Piermattei, V., Development of a sliding device for extended measurements in coastal waters. WIT Transactions on Ecology and the Environment, eds. D. Prats Rico, C. A. Brebbia, Y. Villacampa Esteve, WIT Press: Southampton, 111, pp. 187-196, 2008.

[35] Marcelli, M., Piermattei, V., Petri, A., Madonia, A., Pannocchi, A., Mainardi, U., New Low Cost Technological Developments for Sea Monitoring: Satellite "Sea Truth" and Model Validation. Proc. Oceans From Space” Venice 2010, JRC Scientific and Technical Reports, eds. V. Barale, J. Gower, L. Alberotanza, EUR collection (European Commission, Institute for Environment and Sustainability), JRC Publication 57986, pp. 155-156, 2010. 